\title{
KOALISI DAN PENGELOLAAN KOALISI PADA PEMERINTAHAN JOKO WIDODO-JUSUF KALLA
}

\author{
Efriza \\ Dosen Tetap Program Studi Ilmu Politik di Sekolah Tinggi Ilmu Pemerintahan \\ Abdi Negara (STIP-AN), Jakarta \\ efriza.riza@gmail.com
}

\begin{abstract}
ABSTRAK
Tulisan ini membahas relasi Presiden dengan Dewan Perwakilan Rakyat (DPR) dan pengelolaan koalisi berdasarkan tiga tahun kepemimpinan Presiden Joko Widodo (Jokowi), yang merupakan akibat dari perpaduan antara sistem presidensial dan multipartai. Awalnya, Presiden Jokowi memiliki keinginan untuk mewujudkan koalisi yang berbasis ideologis dan program yang sama (concensus coalition) antar partai politik, namun realitasnya, sulit mewujudkannya disebabkan stabilitas pemerintahan terganggu di awal pemerintahan, akhirnya Presiden Jokowi memilih mewujudkan koalisi "semua partai." Menggunakan dasar pemikiran dari Scott Mainwaring dan David Altman mengenai kombinasi sistem presidensial dan multipartai serta koalisi dalam sistem presidensial, dilengkapi juga dengan beberapa pemikiran lainnya mengenai Koalisi. Berikutnya, dilengkapi analisis dari Otto Kirchheimer tentang Catch All Party, untuk menguraikan tranformasi kepartaian di era modern ini. Disertai pembahasan mengenai orientasi partai-partai politik di Indonesia, berdasarkan uraian Yasraf Amir Piliang tentang nomadisme politik. Berdasarkan realitas dan pemikiran di atas, dihasilkan bahwa kombinasi sistem presidensial dan multipartai dan cara pengelolaan pemerintahan yang dilakukan oleh Presiden Jokowi, adalah pengelolaan koalisi bersifat "gemuk" dengan kepemimpinan yang akomodatif dan cenderung transaksional. Sifat pengelolaan tersebut sebuah upaya menjaga hubungan harmonis antara Presiden dan DPR dengan konsekuensi bahwa Presiden Jokowi melanggar komitmennya untuk mewujudkan koalisi tanpa syarat dan tidak bagi-bagi kursi kekuasaan. Pengelolaan koalisi itu dapat dilakukan karena pilihan partai bergabung sebagai pendukung pemerintahan turut didasari bukan saja kebutuhan pencitraan politik berdasarkan dorongan elektoral dalam pasar politik, tetapi juga dalam upaya partai politik tersebut mendanai kelangsungan hidupnya.
\end{abstract}

Kata kunci: Sistem Presidensial, Koalisi Pemerintahan, Relasi Presiden-DPR, Kepemimpinan Jokowi

\section{ABSTRACT}

This paper discusses the relationship between the President and the House of Representatives and the coalition government based on the three years of President Joko Widodo (Jokowi), who was trapped in inter-institutional competition as a consequence of a mixture of presidential and multi-party systems. Initialy, President Jokowi has the desire to realize a coalition based on ideology and the same program (consensus coalition) between political parties, but the reality, it is difficult to make it happen in government, finally President Jokowi re-elected a coalition of "all parties". Using some of the basics of Scott Mainwaring and David Altman about presidential and multiparty combination systems and coalitions in presidential systems, complemented by several Coalitions. Then, complete the results of Otto Kirchheimer on Catch All Party, to outline the transformation of the party in 
this modern era. Accompanied by discussions on political parties in Indonesia, based on Yasraf Amir Piliang's description of political nomadism. Based on the facts and outcomes, a combination of presidential and multiparty systems and the government's management of government by President Jokowi, which manages a "fat" coalition with accommodative leadership and transactional performances. Matters relating to the harmonious relationship between the President and the House of Representatives with the consequence that the President is committed to realizing an unconditional coalition and not for the power-seats. Coalition management can be done because the choice of the party that develops as a supporter of the government is also based not only on the need for political imagery in order to encourage electoral in the political market, but also in the spirit of the party.

Key words: Presidential System, Coalition Government, the President-Parliament Relations, Leadership Jokowi

\section{Pendahuluan}

Setelah perubahan Undang-Undang Dasar Negara Republik Indonesia Tahun 1945 (UUD NRI Tahun 1945) memengaruhi kewenangan Presiden tepatnya Kewenangan konstitusional seorang Presiden menjadi lebih kecil dan terbatas dibandingkan presiden sebelum reformasi, (Denny Indrayana, 2011: 71). Di era reformasi, Presiden Susilo Bambang Yudhoyono (SBY) merupakan presiden yang kali pertama dipilih langsung oleh rakyat, dan presiden pertama pula yang berhasil menyelesaikan lima tahun masa tugasnya yakni periode 2004-2009, (Denny Indrayana, 2011: 62). Bahkan, jika ditinjau lebih jauh, Presiden SBY adalah Presiden yang dapat menjabat kembali untuk periode kedua dan dapat menyelesaikan jabatannya selama satu dekade.

Keberhasilan Presiden SBY dengan kewenangan konstitusional yang lebih kecil dan terbatas disebabkan oleh model pengelolaan koalisi. Dalam pembentukan pemerintahannya Presiden SBY ini menghasilkan semacam pemerintahan koalisi semua partai. Pemilihan pengelolaan koalisi "besar dan tambun" adalah menjadi jalan keluar dalam pengelolaan pemerintahannya dengan kewenangan konstitusional yang lebih kecil dan terbatas tersebut. Pengalaman memerintah SBY itu, dijadikan contoh oleh Presiden Joko Widodo (Jokowi). Pilihan ini tentu mengingkari janji kampanye Jokowi yang bertekad akan memulai suatu budaya politik yang baru, yaitu konsep koalisi tanpa adanya politik transaksional, (Ari Ganjar Herdiansyah, 2015: 2). Jokowi pun rela mengingkari janjinya mewujudkan koalisi tanpa syarat dengan diawali beralihnya Partai Persatuan Pembangunan (PPP), diikuti Partai Amanat Nasional (PAN), dan diakhiri oleh Partai Golkar sebagai bagian koalisi pendukung pemerintahan.

Dinamika tiga tahun pemerintahan Jokowi mencakup dimensi yang luas dan kompleks. Pilihan untuk menerapkan model pemerintahan koalisi yang bertipe koalisi "semua partai," didasari karena hasil perubahan UUD 1945 justru memperbanyak titik singgung antara lembaga eksekutif dan legislatif. Dari hubungan kedua lembaga ini, dapat dikatakan bahwa ayunan bandul kekuasaan saat ini lebih condong "sarat DPR." Di samping itu, semangat reformasi untuk mempertegas sistem presidensial, yang diwujudkan dalam purifikasi pascaperubahan UUD 1945 ternyata tidak mampu menghilangkan karakter sistem parlementer dalam sistem pemerintahan presidensial di Indonesia. 
Pembongkaran konstruksi presidensialisme dalam UUD 1945 secara signifikan pada Perubahan Pertama tahun 1999, kemudian penguatan kelembagaan DPR pada Perubahan Kedua tahun 2000, bukannya melahirkan keseimbangan kekuasaan antara Presiden dan DPR tetapi justru mengaburkan sistem presidensial yang ingin dibangun melalui Perubahan UUD 1945 tersebut, (Ni'matul Huda dan Imam Nasef, 2017: 39). Ketidakstabilan penyelenggaraan negara, juga terjadi karena pilihan atas kombinasi sistem multipartai dengan sistem pemerintahan presidensial, yang nyatanya adalah berbahaya (innimical) untuk stabilitas politik dan pemerintahan. Berdasarkan realitas tersebut, koalisi "gemuk" atau koalisi "semua partai" menjadi pilihan untuk mewujudkan stabilitas penyelenggaraan negara. Sebab, jika tidak dilakukan pengupayaan "koalisi gemuk" maka partai yang tidak bergabung bisa membentuk poros oposisi di parlemen, tentu saja ini akan menyebabkan sulitnya proposal presiden atau pemerintah untuk diterima di DPR.

Kebijakan pengaturan kepartaian yang menganut sistem multipartai ekstrem turut menghasilkan kondisi yang tidak kondusif bagi sistem presidensial. Efektivitas pemerintah dalam mengambil kebijakan-kebijakan publik sangat bergantung pada dinamika politik yang berkembang di DPR, (Ni'matul Huda dan Imam Nasef, 2017: 39). Di era reformasi ini tidak kondusifnya sistem presidensial juga turut pula didukung oleh absurditas politik dari sepak terjang partai-partai politik dalam berkoalisi. Implikasinya, bisa kita pelajari bahwa selama satu dekade kepemimpinan SBY, kian menunjukkan wajahnya yang lemah sebagai presiden dan lebih sering memosisikan dirinya dalam posisinya yang terjepit dalam pertarungan berbagai partai politik di parlemen. Sementara itu yang terjadi dengan pemerintahan Presiden Jokowi, lebih ironis, Jokowi bukan petinggi partai seperti Presiden SBY, malah dianggap hanya sekadar "petugas partai," yang diberikan amanat oleh Ketua Umum Partai Demokrasi Indonesia Perjuangan (PDI-P), sehingga turut direpotkan oleh ketidaksolidan dukungan dari PDI Perjuangan. Berdasarkan realitas di atas, maka uraian-uraian tersebut akan mengarahkan kita pada beberapa pertanyaan yang akan diulas dalam penelitian ini yakni: Apa saja faktor-faktor yang mendasari koalisi politik pada pemerintahan Jokowi?, Mengapa Pemerintahan Jokowi cenderung memperluas koalisi partai-partai politik pendukung pemerintahannya?, dan Apa implikasinya koalisi politik pendukung pemerintahan tersebut terhadap jalannya pemerintahan Jokowi?

Dalam membahas fokus penelitian dan permasalahan di atas, tulisan ini mengaplikasikan rumusan dari Scott Mainwaring dan David Altman mengenai kombinasi sistem presidensial dan multipartai serta koalisi dalam sistem presidensial, yang dianggap bermasalah. Meski begitu, tak bisa dimungkiri bahwa $\underline{\text { sistem }}$ presidensial di Indonesia adalah pengecualian (anomali) dalam praktek sistem presidensial di dunia, karena harus mengingkari watak sejatinya yang tak mengenal koalisi. Dalam membantu lebih memahami konsep koalisi maka dijelaskan mengenai Koalisi menurut Rainer Adam, Model-Model Koalisi dan Pengelolaan Koalisi dalam Sistem Presidensial utamanya di Indonesia seperti diuraikan oleh Agus Riwanto. Dilengkapi pula dengan analisis Otto Kirchheimer mengenai Catch All Party, untuk menguraikan tranformasi kepartaian di era modern ini, dan disertai dengan orientasi partai-partai politik di Indonesia berdasarkan uraian Yasraf Amir Piliang mengenai Nomadisme Politik. Rumusan dari 
Kirchheimer dan Yasraf ini bermanfaat untuk menunjukkan keterkaitan antara strategi politik kepartaian dan ketidakstabilan sistem presidensial Indonesia. Dan, uraian ini ditutup oleh penafsiran mengenai suatu realitas yang membantah bahwa kombinasi presidensial dengan multipartai menghadirkan instabilitas politik, jika, seorang Presiden memiliki kepiawaian dalam "mengelola" koalisi.

\section{Metode Penelitian}

Penelitian ini dirancang dengan pendekatan kualitatif dengan jenis penelitian menggunakan studi kasus yang bersifat instrumental atau instrumental case study, (Norman K. Denzin dan Yvonna S. Lincoln, 2009: 301). Hal mana kasus yang digunakan adalah tiga tahun lebih kepemimpinan Presiden Jokowi (atau Oktober 2014 sampai dengan Maret 2018), kasus ini memainkan peranan suportif, yang memudahkan pemahaman kita tentang minat-minat yang lainnya, seperti akan membantu mengungkap tak hanya relasi kekuasaan Presiden dan DPR sesudah amandemen UUD 1945 namun juga sebelum amandemen UUD 1945 tersebut. Akhirnya, kita juga tak luput melakukan perbandingan relasi kekuasaan Presiden dengan DPR berdasarkan sebelum dan sesudah amandemen UUD 1945, dan perbandingan hubungan relasi kekuasaan Presiden dengan DPR dan dalam pengelolaan koalisi antara mantan Presiden SBY dengan Presiden Jokowi, meski tidak secara komprehensif.

Teknik pengumpulan data yang digunakan adalah studi literatur dan wawancara yang mendalam. Wawancara dilakukan berdasarkan pedoman wawancara dan beberapa pertanyaan terbuka. Wawancara dilakukan secara mendalam terhadap tiga narasumber yang merupakan pengamat politik (atau peneliti/akademisi) yang tulisan atau penelitiannya turut memengaruhi penelitian ini, tentunya pilihan terhadap ketiga pengamat politik ini didasari juga oleh keahlian mereka mengenai materi pembahasan seperti sistem kepartaian, koalisi, dan sistem presidensial, utamanya juga dengan kasus di Indonesia di era Jokowi dan mantan presiden SBY.

\section{Analisis Sistem Presidensial dan Orientasi Partai-Partai Politik}

Indonesia menerapkan sistem presidensial berkombinasi multipartai, berdasarkan studi Scott Mainwaring, jarang sekali presiden terpilih dari partai mayoritas, dengan terpilihnya minority president, untuk mencapai mayoritas di parlemen maka presiden akan berupaya untuk memperkuat posisinya dengan cara melakukan koalisi, namun membangun koalisi yang stabil jauh lebih sulit dalam demokrasi multipartai presidensial. Sebab, koalisi tidak bersifat mengikat sehingga keinginan bagi partai politik untuk membubarkan koalisi lebih kuat dalam sistem presidensial. Seperti dijelaskan oleh Scott Mainwaring, dalam tulisannya Presidentialism, Multiparty System, and Democracy: The Difficult Combination, sebagai berikut: “... In Presidential systems the president (not the parties) has the responsibility of putting together a cabinet. The president may make prior deals with the parties that support him or her, but these deals are not as binding as they are in parliamentary system. Second, in presidential system, the commitment of individual legislators to support an agreement negotiated by the party leadership is often less secure. Finally, incentives for parties to break a coalitions are stronger in 
presidential system, than in many parliamentary system," (https://www.researchgate.net/ publication/258130109 The_Presidentialism_Multipartism_and_Democracy_The_Difficult_Combination). Jika kita lihat dalam konteks pemerintahan Presiden Jokowi, malah, presiden minoritas bukan saja karena dukungan yang rendah di legislatif, tetapi juga dari internal partai dan koalisi partai pendukungnya. Alasannya jelas, karena Jokowi hanya sebagai "petugas partai" dan bukanlah seorang ketua umum partai seperti presiden-presiden sebelumnya, (Leo Agustino, 2015: 387). Bahkan, dapat ditenggarai bahwa Jokowi tidak dapat dengan mudah memperoleh dukungan dari kawan-kawannya di internal partainya sendiri yakni PDI Perjuangan, karena Jokowi tidak memiliki jabatan struktural di tingkat Dewan Pimpinan Pusat (DPP) PDI Perjuangan sebelum dan saat menjabat Presiden sekarang ini.

Situasi Multipartai di parlemen cenderung membuat presiden melakukan koalisi antar partai-partai di parlemen, terutama untuk memperkuat basis dukungan politik di parlemen. Namun, koalisi dalam sistem presidensial jauh lebih sulit, akhirnya yang terjadi dalam pengelolaan koalisi seperti diuraikan oleh Agus Riwanto, (Agus Riwanto, 2018: 56-57), yaitu: pertama, dalam sistem presidensial, presiden memilih sendiri anggota kabinetnya, yang boleh jadi berasal dari partai oposisi atau partainya sendiri dan kalangan profesional, implikasinya partai-partai tidak memunyai komitmen dukungan terhadap presiden. Kedua, dalam sistem presidensial karena presiden dalam pembentukan kabinetnya jauh lebih cenderung mengakomodasi individu elite partai politik. maka konsekuensinya tidak ada jaminan partai-partai di parlemen akan mendukung pesiden, sebab yang diakomodasi presiden secara kasat mata adalah kepentingan elite partai politik, bukan kepentingan partai politik secara keseluruhan. Di sini tampak perbedaan persepsi akomodasi presiden antara elite partai politik dan partai politik itu sendiri menjadi pemantik tidak solidnya dukungan partai-partai di parlemen pada presiden.

Sebenarnya, apakah itu koalisi? Rainer Adam, (Rainer Adam, 2010: 11), menjelaskan bahwa, istilah 'koalisi' berasal dari kata kerja dalam bahasa Latin "coalescere," yang secara harfiah berarti 'saling menempelkan atau mengikatkan dua hal.' Koalisi pada khususnya merupakan aliansi atau kerja sama untuk periode waktu yang terbatas dalam rangka demi mencapai tujuan tertentu. Dalam politik, tujuan tersebut biasanya adalah mengambil-alih kekuasaan dan memegang pemerintahan. Koalisi yang dimaksud dalam hal ini adalah, antar kelompok atau antar organisasi, untuk mewujudkan tujuan bersama yang tidak dapat dicapai sendirian.

Sekali lagi perlu ditegaskan bahwa membangun koalisi dalam sistem presidensial sangatlah sulit bahkan tidak dianjurkan, maka seperti di sarankan oleh David Altman, dengan mengaplikasikan rumusan David Altman dalam tulisannya The Politics of Coalition Formation and Survival in Multiparty Presidential Democracies: The Case of Uruguay 1989-1999, dengan tegas menganjurkan bahwa setelah mempelajari bangunan koalisi dalam sistem presidensial dikemukakan dua alasan yang tegas menyatakan bahwa koalisi tidak dibutuhkan, uraiannya sebagai berikut: "The first has already been pointed out: under presidential systems governments do not require parliamentary confidence, which means that coalitions are not institutionally necessary. The second reason appears to be the widespread 
belief that presidentialism is not conducive to political cooperation," (http://www.icp.uc.cl/daltman/index_archivos/

Altman-2000-

Party\%20Politics\%206\%20\%283\%29\% 20259-283.pdf).

Sulitnya membangun koalisi juga disebabkan tidak memungkinkan partai politik memilih salah satu di antara kedua pilihan peran yakni tetap mendukung pemerintahan atau mengkritisi pemerintahan. Partai politik diharuskan untuk terusmenerus beralih dari peran kritis ke perannya sebagai pendukung kemapanan, pergeseran yang sulit dijalankan tapi sulit pula dihindari, inilah perkembangan kepartaian modern yakni Catch All Party, seperti diilustrasikan oleh Otto Kirchheimer, sejak memasuki era tahun 1960-an, (Ichlasul Amal, 1996: 49-50).

Lemahnya kesolidan dari partai-partai pendukung pemerintah juga disebabkan pergerakan orientasi partai-partai politik yang tidak pernah memiliki ketetapan dan konsistensi pada tingkat keyakinan atau ideologi politik, yang disebut oleh Yasraf Amir Piliang sebagai Nomadisme Politik. Keyakinan dan ideologi hanya sebuah alat atau tempat persinggahan saja untuk merealisasikan kepentingan kelompoknya bukan kepentingan bangsa atau kepentingan partai mengalahkan kepentingan bangsa yang lebih besar. Sehingga, yang terjadi adalah terlembaganya nomadisme partai, yakni pergerakan partai politik yang terus menerus, pada tingkat citra, lambang, atau ideologi tanpa pernah mampu mengubah watak, karakter, dan budaya politiknya, (Yasraf Amir Piliang, 2005: 156-158).

Nomadisme ini adalah juga sebagai bagian dari strategi politik. Strategi dari partai politik dengan berbagai langkah, manuver, dan strategi politik dalam rangka meraih kemenangan politik. Nomadisme politik ini merupakan wujud dari apa yang disebut ironi politik, yang mana ironi politik memproduksi berbagai bentuk ambivalensi, kontradiksi, inkonsistensi, dan pradoks di dalam politik yang menggiring pada dualisme dalam setiap tindakan, sikap, cara berpikir, manuver politik, dan sebagainya; yang meskipun diterima sebagai bagian dari dunia politik, tetapi menciptakan berbagai bentuk absurditas politik, (Yasraf Amir Piliang, 2005: 170).

Meski demikian, dalam praktiknya koalisi memang merupakan cara paling umum dilakukan oleh pemerintah yang hanya mendapatkan dukungan minoritas, seperti yang ditunjukkan pada hasil pemilu presiden (Pilpres) tahun 2004, 2009, dan 2014. Yang dimaksud oleh Pemerintahan Minoritas (minority government) menurut Jose Antonio Cheibub seperti dikutip oleh Dody Nur Andriyan, (Dody Nur Adriyan, 2012: 197), adalah keadaan di mana pemerintahan tidak dapat mengontrol suara mayoritas di parlemen atau di lembaga legislatif. Melihat realitas di Indonesia, jelas bahwa keniscayaan koalisi adalah sebuah keharusan. Presiden memang harus membangun sebuah koalisi dengan partai-partai politik.

Pengalaman Presiden SBY dalam mengelola pemerintahan dengan upaya partai politik dan presiden terpilih melakukan upaya membangun koalisi antar parpol agar pemerintahan presidensial dapat berjalan stabil dan efektif, meminjam ungkapan Lester G. Seligman dan Cary R. Covington dalam Agus Riwanto, (Agus Riwanto, 2016: 299), yang membagi koalisi dalam tiga model, yakni: koalisi ideologis (concensus coalition), koalisi strategis (conglomerate coalition), dan koalisi pragmatis (exclusife coalition). Koalisi partai politik pendukung pemerintah, 
umumnya di Indonesia adalah pembentukan koalisi pemerintahan "semua partai" atau "koalisi gemuk" atau "koalisi pragmatis."

Harus pula diakui bahwa, tidak selalu kombinasi presidensial dengan multipartai dan koalisi menghadirkan instabilitas politik. Menurut Figueiredo dan Limongi dalam Leo Agustino bahwa, "...the combination of presidensialism and a multiparty system is not necessarily a threat to governmental performance," (Leo Agustino, 2015: 388). Mengonfirmasi pernyataan tersebut, Leo Agustino menyimpulkan, ini karena sangat tergantung pada kepiawaian seorang presiden dalam 'mengelola' partai dan koalisi partai pendukungnya maupun koalisi partai oposisi melalui kekuasaan konstitusional dan partisannya, (Leo Agustino, 2015: 388).

\section{Koalisi Partai Pendukung Pemerintahan}

Kombinasi sistem multipartai dengan presidensial menyebabkan koalisi menjadi barang wajib dalam sistem presidensial, sebab sistem kepartaian di Indonesia adalah sistem multipartai ekstrem dengan suatu realitas bahwa tidak ada satu pun partai yang dominan. Berdasarkan fakta itu, maka hubungan kerja antara presiden-parlemen cenderung konfliktual. Akibatnya, dalam mengambil keputusankeputusan publik maka presiden cenderung terlibat dalam kompromi dan akomodasi kepentingan antara partai di parlemen yang berbeda dengan partai presiden.

Dukungan partai-partai politik yang mayoritas di pemerintahan dan parlemen adalah keniscayaan bagi sistem presidensial yang efektif. Presiden di era Orde Baru tidak memunyai masalah political support, karena Golkar selalu menjadi partai pendukung pemerintah yang memunyai kursi mayoritas mutlak di parlemen. Sehingga, Presiden Soeharto tidak perlu dipusingkan dengan keniscayaan perlunya koalisi di pemerintahannya. Jalannya pemerintahan dan kontrol parlemen berada di bawah kendali penuh Presiden - apalagi UUD 1945 kala itu juga executive heavy constitution. Konsekuensinya, kontrol kepada Presiden menjadi lemah.

Sementara itu, pada era demokratis sekarang, di satu sisi kewenangan Presiden sangat dibatasi, di sisi lain kewenangan kontrol DPR menjadi jauh lebih kuat. Di tambah lagi, Presiden tidak didukung oleh satu partai politik yang mayoritas mutlak sebagaimana era Orde Baru, bahkan mayoritas sederhana saja tidak terjadi.

Persoalan semakin kompleks dan pada akhirnya turut mewarnai pola hubungan eksekutif dan legislatif pada khususnya dan pemerintahan pada umumnya selepas pemilihan presiden. Misalnya, mekanisme Pemilihan Umum Legislatif (Pileg) yang mendahului Pemilihan Umum Presiden (Pilpres) secara mendasar membuka peluang hadirnya sebentuk koalisi yang tidak berkarakter disebabkan koalisi yang terbangun tidak dilandasi oleh sintesa ideologi atau kesamaan visi yang solid, melainkan lebih didasari oleh pemenuhan kuota pencalonan berdasarkan jumlah suara dan kursi, (Parafrasa, Syamsuddin Haris, 2014).

Kondisi di atas juga ditopang oleh model pemilihan presiden dua putaran. Model mayoritas mutlak ini di satu sisi memang akan menyebabkan seorang presiden memiliki legitimasi yang kokoh dihadapan rakyat. Di sisi lain, dengan nuansa politik tak berkarakter di Indonesia, adanya pemilu presiden putaran kedua justru memberi peluang yang besar bagi partai-partai untuk alih suara demi sekadar mendapatkan posisi yang lebih baik, tanpa mengindahkan komitmen yang telah 
dibangun sebelumnya. Jika dikaitkan antara Pemilihan Presiden dua putaran dengan model koalisi, maka terjadi tiga tahap koalisi yang dibangun seperti diungkapkan oleh Firman Noor, sebagai berikut:

\begin{abstract}
"Koalisi tahap pertama diperlukan untuk memenuhi minimal dukungan pencalonan presiden dan wakil presiden, jika terjadi pemilu putaran kedua maka koalisi akan diperbaharui guna menghadapi putaran kedua tersebut, terakhir koalisi dilakukan, guna memperbesar dukungan di DPR," (Hasil wawancara Firman Noor, Peneliti LIPI, 22 Desember 2015).
\end{abstract}

Menyadari bahwa kombinasi sistem presidensial dengan multipartai yang terfragmentasi dengan realitas tidak ada satu partai politik yang memperoleh suara mayoritas, berimplikasi terhadap pembentukan koalisi yang dilakukan oleh Presiden Yudhoyono kala itu, yakni, membentuk governing coalition dan parliamentary coalition. Atau dengan kata lain, berupaya menghadirkan koalisi tahap ketiga tersebut, yakni dalam rangka untuk memperbesar dukungan di DPR. Sementara, di era Presiden Jokowi, agak berbeda. Karena Pilpres diikuti oleh dua pasangan calon dan konsekuensinya tak ada Pilpres putaran kedua.

Ketika Pilpres 2014 lalu, terjadi persaingan keras antar dua kubu pasangan calon yaitu, Prabowo-Hatta Rajasa dengan Jokowi-Jusuf Kalla. Persaingan keras ini ternyata terbawa hingga ke Senayan, maka terjadilah polarisasi dua kekuatan koalisi itu di parlemen. Polarisasi koalisi yang terjadi sesuai preferensi dukungan calon presiden (capres) dan calon wakil presiden (cawapres) yang mana Koalisi Indonesia Hebat (KIH) sebagai pendukung pasangan Jokowi-Jusuf Kalla sesuai dukungan partai politik di DPR diusung oleh PDI Perjuangan, partai Nasdem, PKB, dan partai Hanura dengan total jumlah dukungan anggota parlemen sebanyak 207 anggota atau total suara di parlemen sebesar 36,96 persen. Sedangkan, Koalisi Merah Putih (KMP) pendukung pasangan Prabowo-Hatta Rajasa yang didukung partai politik di DPR pengusungnya adalah partai Gerindra, partai Golkar, PPP, PAN, PKS, dan Partai Demokrat (klaimnya netral) menguasai jumlah dukungan anggota parlemen sebanyak 353 anggota atau total suara di parlemen sebesar 63,03 persen. Menghadapi pusaran konflik KIH dan KMP dalam parlemen, ternyata Koalisi Pendukung Jokowi mengalami kekalahan demi kekalahan dengan skor telak yaitu 60, seperti: Penetapan Undang-Undang MD3, Penetapan Tata Tertib DPR, Pemilihan Pimpinan DPR, Pemilihan Pimpinan Komisi dan Alat Kelengkapan DPR, Penetapan Undang-Undang Pilkada (lewat DPRD), dan Pemilihan Pimpinan MPR.

Menyadari bahwa tidak mudah menjalankan politik pemerintahan dengan hanya sedikit kekuatan di parlemen, konsekuensinya Jokowi akhirnya mengabaikan koalisi tanpa syarat yang digembar-gemborkannya saat Pilpres 2014 lalu, ini dibuktikan dengan pemanfaatan konflik dari kepengurusan PPP atas perbedaan manuver dukungan di Pilpres 2014. KIH yang dari awal telah bermanuver untuk membangun kekuatan baru di parlemen melalui memperluas dukungan partai koalisinya dengan bergabungnya PPP versi Romahurmuziy, respons pun dilakukan dengan menyediakan kursi dari paket calon pimpinan MPR, bahkan juga kepercayaan untuk menduduki kursi kementerian agama. Meski paket pimpinan 
MPR versi KIH kalah, tetapi kompensasi berupa kursi kementerian agama tetap diberikan untuk PPP.

Upaya memperluas koalisi dianggap sebagai cara untuk efektifnya jalannya pemerintahan, karena Presiden lebih membutuhkan political support ketimbang electoral support. Sehingga untuk menjawab tantangan kedua tentang minimnya dukungan politik, tidak ada jalan lain, Presiden mesti melakukan koalisi dan memperluas koalisi, seperti setahun pemerintahannya Presiden Jokowi sibuk melakukan konsolidasi politik. Jokowi pun kembali melakukan hal yang dilakukan sebelumnya oleh SBY yaitu melanggengkan koalisi gemuk, konsekuesinya lagi-lagi prinsip koalisi tanpa syarat tidak mungkin lagi dapat diteruskan setelah dirangkulnya beberapa partai di KMP menjadi koalisi pendukung pemerintahan seperti PAN dan Partai Golkar. Tentu konsekuensinya, pihak koalisi pendukung Jokowi-JK perlu berbagi sumber daya, sebab, there is no such thing as free lunch, untuk mengakomodasinya Jokowi membagi kursi dalam reshuffle kabinet jilid II untuk mengakomodir bergabungnya PAN dan Partai Golkar sebagai pendukung pemerintahan sehingga masing-masing partai memperoleh 1 kursi kementerian. Dengan masuknya PAN dan Partai Golkar sebagai pendukung pemerintah, maka otomatis KIH dan KMP bubar, malah yang terjadi adalah Partai-partai Pendukung Pemerintahan (P4), (Koran Warta Kota, 14 November 2015: 2).

Ironisnya, keyakinan itu terus dipelihara, bahkan Jokowi kembali gagal menunjukkan sikap memegang komitmennya bahwa menterinya tidak boleh merangkap jabatan sebagai pemimpin partai politik, dan membentuk pemerintahan profesional bukan bagi-bagi kursi. Kekhawatiran pemerintahan kembali mengalami "gunjangan" serta persiapan di tahun politik menjelang Pilpres 2019 nanti, menjelaskan realitas bahwa Jokowi menunjukkan kelonggaran (dalam reshuffle keempat) setelah memperbolehkan dua menteri dari Partai Golkar untuk merangkap jabatan di partai politik, yakni Menteri Perindustrian Airlangga Hartarto merangkap sebagai Ketua Umum Partai Golkar dan Menteri Sosial Idrus Marham sebagai Sekretaris Jenderal Partai Golkar. Pilihan sikap Jokowi ini sejalan dengan kesepakatan Partai Golkar yang menyatakan mendukung Jokowi untuk kembali maju sebagai capres dalam Pilpres 2019 mendatang. Di sisi lain, Presiden Jokowi tidak mendepak PAN dari kabinet kerja, meski PAN sering tak sejalan dengan program Presiden Jokowi, seperti menolak pemberlakuan ambang batas pencalonan presiden (presidential threshold) dan menolak penetapan Peraturan Pemerintah Pengganti Undang-Undang (Perppu) tentang Organisasi Kemasyarakatan menjadi undang-undang, (Koran Tempo, 2 November 2017: 7). Meski pada akhirnya, ketika PAN tak mengusung Jokowi pada Pilpres 2019, merasa serba-sulit, menteri dari PAN, Menteri Pendayagunaan Aparatur Negara dan Reformasi Birokrasi, Asman Abnur, memilih mundur. Kemudian, jabatan yang ditinggalkan oleh Asman Abnur digantikan oleh Komjen Syafruddin, yang merupakan dari unsur Kepolisian Republik Indonesia.

Pergeseran peta koalisi mulai dari Pilpres, pembentukan kabinet hingga koalisi di DPR, menunjukkan pergeseran sikap partai politik seiring dengan dinamika isu dan kesempatan politik yang tersedia. Kecenderungan itu menunjukkan sikap pragmatis dari partai-partai politik, sikap itu juga bisa diasumsikan telah terjadinya 
nomadisme politik dari partai-partai politik, sekaligus menunjukkan kelemahan partai-partai politik secara institusi (problem lainnya).

Pilihan bergabung dalam kekuasaan di pemerintahan dan meninggalkan pilihan menjadi oposisi ini terkait pula antara lain, dalam upaya partai politik mendanai kelangsungan hidupnya, dengan kata lain, tidak ada kemandirian partai. Di samping juga suatu kebutuhan pencitraan partai, yaitu sikap partai politik digerakkan oleh dorongan elektoral dalam pasar politik, sehingga akhirnya bergabung sebagai partai-partai pendukung pemerintah.

Implikasi lainnya dari koalisi yang bersifat pragmatis seperti ini, adalah tidak munculnya kompetisi antarpartai politik di parlemen, sehingga tidak tampak perjuangan ideologis partai politik dalam memengaruhi, mengubah, ataupun membentuk kebijakan. Inilah situasi yang terus terjadi dari era pemerintahan SBY hingga pemerintahan Jokowi sekarang ini, tidak terjadinya kekuatan penyeimbang dari oposisi terhadap pemerintahan.

Munculnya partai-partai politik yang bergerak memilih turut bergabung dalam kekuasaan di pemerintahan, menunjukkan bahwa terjadi penurunan identifikasi pemilih partai, yang berdampak terhadap penurunan kepercayaan kepada partai politik. Tentu saja akhirnya, melemahnya ikatan antara partai politik dan pengikut, situasi ini akan menimbulkan volatilitas yang lebih tinggi dalam pemilu. Wajar akhirnya dalam pemilu, para pemilih semakin enggan untuk mengidentifikasi diri dengan partai politik yang sama selama suatu siklus pemilihan, dan terdapat kecenderungan yang kuat untuk mengubah identifikasi mereka dari pemilihan ke pemilihan, (John T. Ishiyama dan Marijke Breuning (Ed), 2013: 260-261).

Jika demikian, ternyata ayunan dari sistem presidensial dengan kombinasi sistem multipartai ekstrem yang terjadi di era kepemimpinan pemerintahan Presiden Jokowi maupun pemerintahan SBY (sebelumnya), menurut Syamsuddin Haris bahwa, "untuk menghindari terjadinya deadlock malah terjadinya upaya memperluas dukungan dalam koalisi pemerintahan, yang juga tak bisa dilepaskan dari lemahnya orientasi partai-partai politik di Indonesia," (Hasil Wawancara Syamsuddin Haris, Peneliti LIPI, 28 Desember 2015).

\section{Peniruan Pengelolaan Koalisi Dalam Upaya Melanggengkan Kekuasaan}

Pengelolaan pemerintahan selama satu dekade kepemimpinan Presiden SBY menunjukkan bahwa kecenderungan terjadinya pemerintahan yang terbelah, karena partai internal dari SBY yakni partai Demokrat hanya minoritas di DPR. Ini adalah konsekuensi dari sistem multipartai yang terfragmentasi dan terpolarisasi kepentingan ideologi dan politik, tetapi sayangnya tidak ada satu pun partai yang dominan. Permasalahan semakin kompleks, karena perbedaan peta kekuasaan antara Presiden dan DPR, sebab partai politik pemenang pemilihan presiden tidak menjadi kekuatan yang dominan pula di lembaga legislatif, sehingga Presiden SBY banyak mendengarkan partai-partai politik dan fraksi-fraksi yang ada di DPR. Akibatnya dalam masa kepemimpinan Presiden SBY, isu utama dalam hubungan eksekutif dan legislatif adalah terkait dengan koalisi partai-partai politik.

Hubungan Presiden dan DPR selama satu dekade kepemimpinan Presiden SBY cenderung fluktuasi, meski demikian hubungan Presiden SBY dan DPR di masa itu belum dapat dikategorikan sebagai bermasalah, karena tidak ada konflik 
yang dahsyat antara kedua lembaga politik tersebut. Hanya yang berkembang adalah perbedaan pendapat antara kedua lembaga, sebab memang salah satu fungsi DPR adalah melakukan pengawasan terhadap eksekutif. Perbedaan pendapat tentu saja tidak selalu sama dengan konflik yang perlu dikhawatirkan, seperti yang pernah terjadi di era pemerintahan Abdurrahman Wahid sehingga berakibat pemakzulan. Tentu saja hal ini semakin menarik perhatian kita, apa yang menyebabkan kepemimpinan Presiden SBY bisa tetap menjaga hubungan yang harmonis dengan DPR dan menghindari terjadinya konflik, dan tampaknya Presiden Jokowi begitu mencermati pengelolaan koalisi di masa Pemerintahan SBY dalam upaya melanggengkan kekuasaannya, sehingga Presiden Jokowi pun tak tampak ragu lagi memilih mengikuti cara pengelolaan kekuasaan mantan presiden SBY tersebut, uraiannya sebagai berikut, Moch Nurhasim dan Ikrar Nusa Bhakti (Ed), 2009: 40).

Jika kita cermati, ternyata faktor kepemimpinan dan gaya memerintah seorang presiden menjadi penyokong kelangsungan sistem presidensial dengan kombinasi multipartai, utamanya Presiden SBY berhasil dalam mengelola politik secara efektif. Ini disebabkan oleh kecenderungan Presiden SBY yang akomodatif yang dilandasi ingin membangun demokrasi yang mulai tumbuh. Misalnya, keputusan SBY untuk membentuk koalisi guna mendukung pemerintahannya, selain didasarkan pada pemikiran strategis, juga bisa dilihat sebagai bagian dari gaya atau pendekatan kepemimpinannya yang cenderung akomodatif, (Djayadi Hanan, 2014: 181).

Pengalaman SBY ini tentu saja tak berbeda dengan kepemimpinan Presiden Jokowi yang selama tiga tahun pemerintahannya telah menunjukkan juga cenderung akomodatif. Ini ditunjukkan dengan Jokowi mulai merangkul sebanyak-banyaknya partai politik untuk menjadi mitra koalisi seperti PPP, PAN, dan terakhir Partai Golkar. Bahkan, menjelang Pilpres 2019 mendatang, memasuki tahun politik dalam perombakan kabinet jilid IV pada Januari 2018 lalu, tampak bahwa Presiden Jokowi semakin "nyaman" di bawah naungan beringin ketimbang berada di kandang Banteng. Analisis mengenai betapa pentingnya mitra koalisi Partai Golkar dibandingkan dengan PDI Perjuangan sebagai partai tempat bernaungnya Presiden Jokowi, diungkapkan oleh Syamsuddin Haris yaitu:

"Sejak lama, dari pihak pemerintah, orang yang amat dipercaya oleh Jokowi sebagai negosiator, dalam rangka merangkul Partai Golkar bergabung dalam kabinet yakni melalui Luhut Binsar Panjaitan, yang memang bagian dari elite Golkar. Luhut, sudah dipercaya sejak ia sebagai kepala staf Presiden, hingga sekarang menjabat Menteri Koordinator Maritim dan Sumber Daya Republik Indonesia," (Hasil wawancara Syamsuddin Haris, Peneliti LIPI, 28 Desember 2015).

Permasalahan utama dari relasi Presiden dengan DPR memang berada pada partai-partai politik yang menjadi mitra koalisi pemerintah. Dalam wilayah eksekutif, mereka mendapat posisi dalam kabinet, namun dalam wilayah legislatif, posisinya menjadi tidak jelas tergantung dari kepentingan partai politiknya masingmasing. Akhirnya, relasi lembaga eksekutif dengan legislatif menjadi tidak harmonis, (Muhammad Sabri S. Shinta, 2012: 66). Kondisi ini menimbulkan 
ketegangan-ketegangan antara Presiden dan partai-partai politik mitra koalisi. Sehingga, koalisi yang dibangun oleh presiden SBY kala itu, dan Presiden Jokowi adalah koalisi besar atau Presiden Minoritas dengan Pemerintahan Mayoritas, tetapi tidak solid.

Yang membedakan dengan pengelolaan pemerintahan oleh SBY, adalah ketidaksolidan partai pendukung Presiden Jokowi utamanya malah terjadi di partai internalnya sendiri yaitu PDI Perjuangan, yang didasari karena persoalan Jokowi hanya sebagai "petugas partai" dan bukanlah seorang ketua umum partai seperti presiden-presiden sebelumnya, (Leo Agustino, 2015: 388). Dengan kata lain, walaupun Presiden memiliki dukungan besar di DPR, tetapi Presiden seringkali kehilangan dukungan partisan dalam menggolkan agenda-agenda pemerintahannya.

Sebab, PDI Perjuangan dan pemimpin partai itu juga punya agenda yang belum tentu cocok dengan agenda pemerintah, meski secara normatif tentu sejalan. Dukungan PDI Perjuangan, misalnya, kepada calon Kepala Kepolisian Komisaris Jenderal Budi Gunawan, termasuk dalam konflik Budi Gunawan dengan Komisi Pemberantasan Korupsi (KPK), adalah contoh bahwa agenda partai politik utama pendukung Presiden tidak mudah disesuaikan dengan agenda Presiden dalam upaya pemberantasan korupsi, serta agenda Presiden untuk memperoleh wilayah dukungan dari masyarakat terhadap rezim dan pemerintahannya. Hal yang sama seperti, upaya pelemahan KPK, melalui revisi undang-undang KPK, justru dimotori oleh kader PDI Perjuangan di DPR yang bertentangan dengan aspirasi dari masyarakat untuk penguatan KPK, (Djayadi Hanan, 2015: 11).

Celakanya, lemahnya Jokowi ketika berhadapan dengan PDI Perjuangan semakin terlihat dalam tiga tahun lebih kepemimpinannya. Pemerintahan Jokowi berupaya mempertemukan di antara berbagai kepentingan misalnya antara kepentingan partai dan kepentingan masyarakat, dengan menggunakan konsep winwin solution yang menjadi pilihan dari Jokowi dalam mengelola wilayah dukungan, sehingga arah Jokowi dalam kepemimpinannya tak berbeda jauh dengan SBY, terjadinya politik akomodasi, yang tentunya rentan dengan transaksional dalam memerintah. Seperti, ditenggarai dengan diterimanya pasal-pasal kontroversial yakni: Pasal 73 tentang pemanggilan paksa anggota Dewan, Pasal 122 huruf k tentang penambahan kewenangan Mahkamah Kehormatan Dewan (MKD), dan Pasal 245 tentang pemanggilan anggota DPR yang harus disetujui MKD dan Presiden; dalam pembahasan revisi Undang-Undang MPR, DPR, DPD, dan DPRD (disebut UU MD3) yang ditukar dengan jatah kursi Wakil Ketua DPR bagi PDI Perjuangan.

Kontroversi keputusan transaksional ini juga pernah terjadi di era pemerintahan Presiden SBY. Saat itu DPR menyetujui Rancangan Undang-Undang (RUU) Pemilihan Kepala Daerah (Pilkada) yang isinya membawa Indonesia mundur ke masa Orde Baru, yaitu kepala daerah tidak lagi dipilih secara langsung, melainkan oleh DPRD. Pilihan itu dilakukan untuk tercapainya pertukaran antara diterimanya pasal kontroversi itu dan berhasilnya Partai Demokrat menduduki kursi wakil ketua MPR. Setelah dihujani kritik, Presiden Yudhoyono akhirnya mengeluarkan keputusan peraturan pemerintah pengganti undang-undang (Perppu) yang menganulir diundangkannya UU Pilkada itu. 
Meski begitu, harus diakui akan kemampuan kepemimpinan Presiden SBY kala itu, dalam upayanya terus mengelola koalisi besar. Walau penuh dengan ketegangan dalam internal koalisi, namun Demokratisasi dan stabilitas politik serta pemerintahan yang lebih efektif itu, ternyata mampu mengondisikan peningkatan Produk Domestik Bruto (PDB) tahunan menjadi sekitar 6\%, selama kurang lebih satu dekade. Maka kemajuan demokrasi dan politik serta pemerintahan, dan juga didukung perkembangan kemajuan ekonomi, terkombinasikan menjadi kekuatan pendukung Presiden SBY, untuk berkuasa melalui kemenangan dua kali Pemilu tersebut, (Hasil Wawancara Arbi Sanit, Pengamat Politik dan Mantan Dosen UI, 08 Januari 2016). Begitu pula dengan Presiden Jokowi, setelah berhasil merangkul partai-partai koalisi di KMP, maka tak ada lagi riak-riak di parlemen, dibandingkan masih tetap diupayakannya koalisi tanpa syarat, ketidaknaifan mengelola dukungan partai-partai politik meski dibayar mahal dengan pengabaian komitmen awal sebelum memerintah, ternyata PDB Indonesia tahun 2017 masih cukup tinggi sekitar 5,6\%, (Dokumen, Sri Mulyani, 2017).

Problematika sistem presidensial dan multipartai ini, ternyata bisa diselesaikan oleh adanya faktor gaya memerintah seorang presiden yang akomodatif meski kecenderungan transaksional tak bisa dihindari. Fakta ini jelas menunjukkan bahwa kombinasi sistem presidensial dengan multipartai tidak selalu menimbulkan instabilitas politik, ketidakstabilan penyelenggaraan pemerintah, jika seorang presiden memiliki kepiawaian dalam 'mengelola' partai dan koalisi pendukungnya maupun koalisi oposisi melalui kekuasaan konstitusionalnya dan partisannya, (Leo Agustino, 2015: 388).

Selama era reformasi ini, menunjukkan bahwa partai-partai politik sebagai institusional masih lemah, sehingga menjalankan strategi politik bersifat nomadisme politik. Dibalik kelemahan institusional partai, tentulah memberikan keuntungan bagi SBY dan Jokowi dalam mengelola pemerintahan. Selama dua periode kepemerintahan SBY dan tiga tahun lebih dari kepemimpinan Presiden Jokowi, hanya terjadi ketegangan politik antara Presiden dan DPR.

Meski harus diakui di bawah kepemimpinan SBY dan Presiden Jokowi, mengindikasikan adanya demokrasi yang tersandera dan terjebak dari pilihan SBY dan Jokowi selama menjalankan pemerintahannya sendiri yang sangat menghindari adanya konflik politis dengan kepemimpinannya yang cenderung akomodatif, yang juga didukung oleh lemahnya institusionalisasi partai-partai tersebut. Bahkan, di masa Jokowi cenderung lebih meluas politik transaksionalnya, akomodir tak hanya untuk partai-partai politik tetapi juga tim pemenangan pasangan Jokowi-JK yang terdiri dari berbagai relawan, sehingga bagi-bagi jabatan terjadi pula di kursi BUMN dan jabatan Duta Besar.

Dari realitas di atas, tampak bahwa tiga tahun lebih pemerintahan Jokowi menunjukkan Presiden Jokowi tidak naif atas dukungan-dukungan partai politik untuk pemerintahan, sehingga Jokowi rela mengabaikan berbagai janji politik di masa pembentukan pemerintahan, seperti janjinya membentuk koalisi tanpa syarat, penunjukkan menteri bukan upaya bagi-bagi kursi, dan tidak adanya jabatan rangkap antara pembantu presiden dan sebagai pejabat partai politik. Dari situasi ini juga menjelaskan bahwa koalisi menjadi keniscayaan karena perpaduan antara sistem presidensial dan multipartai, tetapi pilihan itu dapat berjalan dengan baik dalam 
mendukung stabilitas penyelenggaraan negara meski disertai dengan politik transaksional.

\section{Simpulan}

Periode tiga tahun lebih dari pemerintahan Jokowi pasca amandemen UUD 1945, menunjukkan bahwa terjadinya ketegangan relasi kekuasaan Presiden dengan DPR, yang disebabkan kombinasi sistem presidensial dan sistem multipartai, meski hubungan Presiden dengan DPR selama kepemimpinan Presiden Jokowi belum dapat dikategorikan bermasalah. Sebab, tidak terjadi konflik antara kedua lembaga tersebut melainkan hanya terjadi ketegangan politik saja yang disebabkan oleh perbedaan pendapat antara kedua lembaga dan disebabkan peran dan fungsi DPR dalam melakukan pengawasan terhadap eksekutif.

Hal ini bisa terjadi disebabkan oleh: pertama, gaya memerintah Presiden yang cenderung akomodatif dan transaksional, dan kedua, lemahnya institusional partai dan cenderung pragmatis. Lemahnya institusional partai dan perilaku cenderung pragmatis dapat kita anggap juga menyebabkan terjadinya penerapan strategi politik berupa nomadisme partai, seperti diuraikan oleh Yasraf Amir Piliang. Perilaku nomadisme politik itu ternyata juga seirama dengan perkembangan kepartaian modern yakni catch all party, seperti diuraikan oleh Otto Kirchheimer, tentu konsekuensinya adalah mudahnya partai-partai berganti "baju" dalam dukungan koalisinya, dari koalisi oposisi menjadi koalisi pendukung pemerintah, dan dari koalisi pendukung pemerintah tetapi tetap bermanuver sebagai koalisi oposisi.

Pilihan partai bergabung sebagai pendukung pemerintahan turut didasari bukan saja kebutuhan pencitraan politik berdasarkan dorongan elektoral dalam pasar politik, tetapi juga dalam upaya partai politik tersebut mendanai kelangsungan hidupnya. Namun, upaya membentuk koalisi "semua partai," juga dapat terjadi karena merupakan bagian dari upaya pemerintah menjaga stabilitas penyelenggaraan negara dengan konsekuensi tak luput terjadinya politik transaksional yang dilakukan oleh pemerintahan Jokowi, asumsi ini mengonfirmasi atas tiga pertanyaan di awal penelitian yakni mengenai faktor-faktor yang mendasari koalisi politik pada pemerintahan Jokowi, alasan Pemerintahan Jokowi cenderung memperluas koalisi partai-partai politik pendukung pemerintahannya, dan implikasinya koalisi politik pendukung pemerintahan tersebut terhadap jalannya pemerintahan Jokowi.

Koalisi yang dibangun dengan bersifat pragmatis semata, tentu berdampak terhadap tidak munculnya kompetisi antarpartai politik di parlemen, sehingga tidak tampak perjuangan ideologis partai politik dalam memengaruhi, mengubah, ataupun membentuk kebijakan, serta pengawasan DPR terhadap pemerintah menjadi lunak, tetapi ini adalah pilihan Presiden Jokowi agar memperoleh political support tidak semata electoral support. Inilah situasi yang terus terjadi dari era pemerintahan SBY hingga pemerintahan Jokowi sekarang ini, terjadinya pengelolaan koalisi "semua partai." Implikasi lainnya, dari perilaku partai-partai politik yang bergerak bergabung dalam mendukung kekuasaan di pemerintahan, menyebabkan terjadinya penurunan identifikasi pemilih partai, yang berdampak pula terhadap penurunan kepercayaan kepada partai politik. Tentu saja akhirnya, melemahnya ikatan antara partai politik dan pengikut, yang akan menimbulkan volatilitas yang lebih tinggi 
dalam pemilu. Wajar akhirnya dalam pemilu, para pemilih semakin enggan untuk mengidentifikasi diri dengan partai politik yang sama selama suatu siklus pemilihan, dan terdapat kecenderungan yang kuat untuk mengubah identifikasi mereka dari pemilihan ke pemilihan.

Gaya memerintah yang cenderung akomodatif merupakan paling krusial dalam mengelola sistem presidensial, bisa diasumsikan bahwa sistem presidensial di Indonesia dapat berjalan dengan baik, jika dikelola dengan politik transaksional. Seperti ditunjukkan dari gaya memerintah Jokowi yang berupaya mempertemukan di antara berbagai kepentingan misalnya antara kepentingan partai dan kepentingan masyarakat, antara kepentingan pemerintah dengan kepentingan masyarakat, konsep win-win solution yang menjadi pilihan dari pola Jokowi dalam mengelola wilayah dukungan, yang mana konsep ini merupakan bagian dari realitas politik akomodatif dan cenderung transaksional dalam kepemimpinannya.

Konsep win-win solution ini ternyata berhasil dalam menutupi kelemahan diri Presiden Jokowi ketika memerintah, seperti tatkala terjadinya perbedaan kepentingan antara PDI Perjuangan dengan kepentingan pemerintah, dalam kasus dukungan PDI Perjuangan, misalnya, kepada calon Kepala Kepolisian Komisaris Jenderal Budi Gunawan, termasuk dalam konflik Budi Gunawan dengan KPK, adalah contoh bahwa agenda partai utama pendukung Presiden tidak mudah disesuaikan dengan agenda Presiden dalam upaya pemberantasan korupsi, serta agenda Presiden untuk memperoleh wilayah dukungan dari masyarakat terhadap rezim dan pemerintahannya, solusi win-win dipilih dengan "menggeser" Budi Gunawan dari keputusan menjadikan calon Kapolri menjadi wakil kapolri.

Asumsi-asumsi dari kesimpulan di atas, tentu saja akan mudah terbantahkan jika: gaya memerintah Presiden cenderung tidak akomodatif dan transaksional ketika berhadapan dengan DPR; dan partai-partai politik sudah terlembaga; sehingga ketegangan politik yang mengarah deadlock hingga krisis pemerintahan tetap bisa terjadi.

Sehingga demikian, penutup dari kesimpulan ini, adalah selama tiga belas tahun lebih, dari dua periode (satu dekade) pemerintahan Presiden SBY dan tiga tahun lebih kepemimpinan Presiden Jokowi, pengelolaan sistem pemerintahan Indonesia dijalankan dengan gaya kepemimpinan akomodatif dengan cenderung transaksional, yang disebabkan oleh belum kompatibelnya antara sistem kepartaian bersifat multipartai dengan sistem pemerintahan yang bersifat presidensial. 


\section{Daftar Pustaka}

\section{Buku:}

Adam, Rainer, (2010), Masa Depan Ada di Tengah: Toolbox Manajemen Koalisi, Jakarta: Friedrich Naumann Stiftung, 2010.

Amal, Ichlasul, (1996), Teori-Teori Mutakhir Partai Politik (edisi revisi), Yogyakarta: Tiara Wacana Yogya.

Andriyan, Dody Nur, (2012), Hukum Tata Negara dan Sistem Politik: Kombinasi Presidensial dengan Multipartai di Indonesia, Yogyakarta: Deepublish.

Denzin, Norman K., \& Lincoln, Yvonna S., (2009), Handbook of Qualitative Research, terjemahan Dariyatno, at.all, Yogyakarta: Pustaka Pelajar.

Hanan, Djayadi, (2014), Menakar Presidensialisme Multipartai Di Indonesia: Upaya Mencari Format Demokrasi yang Stabil dan Dinamis dalam Konteks Indonesia, Bandung: Mizan.

Haris, Syamsuddin, (2014), Praktik Parlementer Demokrasi Presidensial Indonesia, Yogyakarta: Andi Offset.

Herdiansah, Ari Ganjar, (2015), Paradoks Koalisi Tanpa Syarat: Suatu Tinjauan dari Perspektif Sosiologi Politik, Jakarta: RajaGrafindo Persada.

Huda, Ni'matul, dan Nasef, M. Imam, (2017), Penataan Demokrasi dan Pemilu Di Indonesia Pasca Reformasi, Jakarta: Kencana.

Indrayana, Denny, (2011), Indonesia Opitimis, Jakarta: Bhuana Ilmu Populer.

Ishiyama, Jhon T., \& Breuning, Marijke, ed., (2013), Ilmu Politik Dalam Paradigma Abad Ke-21 (jilid 1), Jakarta: Kencana.

Nurhasim, Moch., \& Nusa Bhakti, Ikrar, ed., (2009), Sistem Presidensial dan Sosok Presiden Ideal, Yogyakarta: Pustaka Pelajar.

Piliang, Yasraf Amir, (2005), Transpolitika: Dinamika Politik di Dalam Era Virtualitas, Yogyakarta: Jalasutra.

Riwanto, Agus, (2016), Hukum Partai Politik dan Hukum Pemilu di Indonesia: Pengaruhnya Terhadap Penyelenggaraan Pemilu Berkualitas dan Sistem Pemerintahan Presidensial Efektif, Yogyakarta: Thafa Media, 2016. 
--------, (2018), Desain Sistem Pemerintahan Antikorupsi: Konsep Pencegahan Korupsi Politik dalam Sistem Pemerintahan, Partai Politik dan Pemilu, Malang: Setara Press.

S. Shinta, Muhammad Sabri, (2012), Presiden Tersandera: Melihat Dampak Kombinasi Sistem Presidensial-Multipartai dalam Pemerintahan SBYBoediono, Jakarta: RM Books.

\section{Jurnal, Tulisan/Berita Surat Kabar:}

Djayadi Hanan, Setahun Pemerintahan Joko Widodo Tiga Tantangan Jokowi, Koran Tempo, 27 Oktober 2015.

Istman Musaharun dan Dias Prasongko, Jokowi Belum Berniat Depak PAN, Koran Tempo, 2 November 2017.

Koalisi Partai Politik Pendukung Pemerintah: KIH Ganti Nama Jadi P4, Warta Kota, 14 November 2015.

Agustino, Leo, Satu Tahun Pemerintahan Jokowi: Transaksional dan Transformasional, dalam Analisis CSIS, Vol. 44, No. 4, 2015.

\section{Dokumen Resmi:}

Indrawati, Sri Mulyani, Projo Public Lecture, makalah disajikan dalam Projo Public Lecture, Jakarta, 22 November 2017.

\section{Internet (artikel dalam jurnal online)}

Altman, David, (2000), The Politics of Coalition Formation and Survival in Multiparty Presidential Democracies: The Case of Uruguay 1989-1999, Party Politics, Vol. 6 No. 3, (http://www.icp.uc.cl/daltman/index archivos/Altman2000-Party\%20 Politics\%206\%20\%283\%29\% 20259-283.pdf, diakses 15 Februari 2018).

Mainwaring, Scott, (1993), Presidentialism, Multiparty System, and Democracy: The Difficult Combination, Comparative Political Studies, Vol. 26 No. 2, hlm. 220-222, (https://www.researchgate.net/publication/258130109_The_Presidentialism Multipartism_and_Democracy_The_Difficult_Combination, diakses 15 Februari 2018). 


\section{Wawancara:}

Arbi Sanit, Pengamat Politik dan mantan Dosen UI, 8 Januari 2016, Jakarta.

Firman Noor, Peneliti di Pusat Penelitian Politik Lembaga Ilmu Pengetahuan Indonesia (P2P LIPI), 22 Desember 2015, Jakarta.

Syamsuddin Haris, ahli politik dan peneliti Pusat Penelitian Politik Lembaga Ilmu Pengetahuan Indonesia (P2P LIPI), 28 Desember 2015, Jakarta. 